\title{
EKSISTENSI MASYARAKAT ADAT DALAM MEMPERTAHANKAN HAK ATAS TANAH ULAYAT (STUDI MASYARAKAT ADAT KEBATINAN MUARA SAKAL KABUPATEN PELALAWAN)
}

\author{
Wismar Harianto \\ Fakultas Hukum Universitas Lancang Kuning, \\ Email : wismarriau@gmail.com
}

\begin{abstract}
This study aims to identify, study and analyze the existence of the Muara Sakal traditional community in defending their customary rights over their customary law communities' lands. Where the adat community of Muara Sakal kebatinan has a large area of ulayat land which did not escape the "annexation" of various parties. The results showed that the customary rights to land were still recognized, managed and controlled jointly by the community through a leadership system in a customary institution and the customary law community of Muara Sakal Kebatinan which was led by an inner person and until now still exists in defending their customary land rights. from the control of private parties (corporations) and the community as individuals who control the ulayat lands of the Muara Sakal customary law community without rights, this can be seen from the existence of several lawsuits filed by Batin Muara Sakal at the Pelalawan District Court.
\end{abstract}

\section{Keywords: Existence, Indigenous Peoples, Ulayat}

\begin{abstract}
Abstrak
Penelitian ini bertujuan untuk mengetahui, mengkaji dan menganalisis keberadaan masyarakat hukum adat kebatinan Muara Sakal dalam mempertahankan hak ulayat atas tanah masyarakat hukum adat mereka. Dimana masyarakat adat kebatinan muara sakal memiliki tanah ulayat yang luas yang tak luput dari "pencaplokan" dari berbagai pihak. Hasil penelitian menunjukan bahwa hak ulayat atas tanah masih diakui, dikelola dan dikuasai bersama oleh masyarakat melalui sistem kepemimpinan dalam suatu kelembagaan adat dan masyarakat hukum adat Kebatinan Muara sakal yang di pimpin oleh seorang batin dan sampai saat ini masih eksis dalam mempertahankan hak atas tanah ulayat mereka dari penguasaan para pihak swasta (korporasi) maupun masyarakat secara perorangan yang menguasai tanah ulayat Masyarakat hukum adat Muara Sakal tanpa hak, hal ini dapat dilihat dari adanya beberapa gugatan yang dilakukan oleh Batin Muara Sakal di Pengadilan Negeri Pelalawan.
\end{abstract}

Kata Kunci: Eksistensi, Masyarakat Adat, Ulayat. 


\section{Pendahuluan}

Keberadaan masyaraat adat dalam Undang-Undang Dasar Negara Republik Indonesia Tahun 1945 hasil amandemen mendapatkan legalitas dan penghormatan sebagaimana di tuangkan dalam pasal $18 \mathrm{~B}$ ayat (2) ${ }^{1}$ dan ketentuan Pasal 28 I ayat (3) ${ }^{2}$ Pasal tersebut memberikan kedudukan kostitusional kepada masyarakat hukum adat dalam hubungannya dengan negara. Urgensi dari kedua substansi ketentuan konstitusional tersebut berbeda. Ketentuan Pasal 18B ayat (2) ditempatkan sebagai bagian dari Pemerintahan Daerah (Bab VI), sedangkan ketentuan Pasal 28I ayat (3) ditempatkan sebagai bagian dari Hak Asasi Manusia (Bab XA).

Negara mengakui dan menghormati kesatuan masyarakat hukum adat beserta hak tradisionalnya sepanjang masih hidup dan sesuai dengan perkembangan masyarakat dan Prinsip Negara Kesatuan Republik Indonesia. Implementasi dari kesatuan masyarakat hukum adat tersebut telah ada dan hidup di wilayah Negara Kesatuan Republik Indonesia, seperti: huta/nagori di Sumatera Utara, gampong di Aceh, nagari di Minagkabau, marga di Sumatera bagian selatan, tiuh atau pekon di Lampung, desa pakraman/desa adat di Bali, lembang di Toraja, banua dan wanua di Kalimantan, dan negeri di Maluku. ${ }^{3}$

Masyarakat Hukum Adat adalah Warga Negara Indonesia yang memiliki karakteristik khas, hidup berkelompok secara harmonis sesuai hukum adatnya, memiliki ikatan pada asal usul leluhur dan/atau kesamaan tempat tinggal, terdapat hubungan yang kuat dengan tanah dan lingkungan hidup, serta adanya sistem nilai yang menentukan pranata

${ }^{1}$ Undang-Undang Dasar Negara Republik Indonesia Tahun 1945 Pasal 18B ayat (2), yang menyatakan: "Negara mengakui dan menghormat kesatuan-kesatuan masyarakat hukum adat beserta hak-hak tradisionalnya sepanjang masih hidup dan sesuai dengan perkembangan masyarakat dan prinsip Negara Kesatuan Republik Indonesia, yang diatur dalam undang-undang".

2 Undang-Undang Dasar Negara Republik Indonesia Tahun 1945 Pasal 18 I ayat (3), yang menyatakan: "Identitas budaya dan hak masyarakat tradisional dihormati selaras dengan perkembangan zaman dan peradaban"

${ }_{3}$ Nur Apri Ramadan I. Usman, Eksistensi Masyarakat Hukum Adat Dalam Penguatan Desa Adat Di Desa Bentenan Kabupaten Minahasa Tenggara, Jurnal, Lex Et Societatis, Vol. III/no. 7/ags/2015, hlm. 125 
ekonomi, politik, sosial, budaya, hukum dan memanfaatkan satu wilayah tertentu secara turun temurun. ${ }^{4}$

Lebih tegas Undang-Undang Nomor 6 Tahun 2014 tentang Desa Bab XIII Ketentuan Khusus Desa Adat Pasal $96^{5}$ memberikan amanah kepada kepala daerah melakukan penataan kesatuan masyarakat hukum adat dan ditetapkan menjadi Desa Adat. Desa Adat adalah sebuah kesatuan masyarakat hukum adat yang secara historis mempunyai batas wilayah dan identitas budaya yang terbentuk atas dasar teritorial yang berwenang mengatur dan mengurus kepentingan masyarakat Desa berdasarkan hak asal usul. Pada dasarnya kesatuan masyarakat hukum adat terbentuk berdasarkan tiga prinsip dasar, yaitu genealogis, teritorial, dan/atau gabungan genealogis dengan teritorial.

Teritorial atau Wilayah Adat adalah tanah adat yang berupa tanah, air, dan/atau perairan beserta sumber daya alam yang ada di atasnya dengan batas-batas tertentu, dimiliki, dimanfaatkan dan dilestarikan secara turun-temurun dan secara berkelanjutan untuk memenuhi kebutuhan hidup masyarakat yang diperoleh melalui pewarisan dari leluhur mereka atau gugatan kepemilikan berupa tanah ulayat atau hutan adat. $^{6}$ Sedangkan tanah ulayat merupakan bidang tanah yang berada dalam lingkup hak ulayat suatu masyarakat hukum adat tertentu.

Implementasi dari kesatuan masyarakat hukum adat tersebut telah ada dan hidup di wilayah Provinsi Riau yang memiliki sistem pemerintahan yang khas dan beranekaragam, seperti Pemerintahan Kampung, Pemerintahan Kepenghuluan, Pemerintahan Nagari, maupun Pemerintahan Perbatinan. Salah satu kesatuan masyarakat hukum adat

${ }^{4}$ Pasal 1 angka 12 Peraturan Daerah Provinsi Riau Nomor 2 Tahun 2019 Tentang Susunan Kelembagaan, Pengisian Jabatan Dan Masa Jabatan Kepala Desa Adat

${ }^{5}$ Undang-Undang Nomor 6 Tahun 2014 tentang Desa pasal 96 menyatakan "Pemerintah, Pemerintah Daerah Provinsi, dan Pemerintah Daerah Kabupaten/Kota melakukan penataan kesatuan masyarakat hukum adat dan ditetapkan menjadi Desa Adat"

${ }^{6}$ Pasal 1 angka 13 Peraturan Daerah Provinsi Riau Nomor 2 Tahun 2019 Tentang Susunan Kelembagaan, Pengisian Jabatan Dan Masa Jabatan Kepala Desa Adat 
yang masih eksis di provinsi Riau adalah kesatuan masyarakat hukum adat Kabatinan Muara Sakal yang terletak di Kelurahan Langgam Kecamatan Langgam Kabupaten Pelalawan.

Bahwa keberadaan kebatinan Muara Sakal, berawal pada masa Kerajaan Pelalawan yang tumbuh dan berkembang seiring sejalan dengan Kerajaan Pelalawan dimana Pranata Pemerintahan Adat, harta kekayaan dan/atau benda-benda adat, norma hukum adatnya serta kesatuan masyarakat hukum adatnya yang bersifat teritorial/unsur wilayah hukum adatnya masih terpelihara dengan baik hingga saat ini dan tidak bertentangan dengan ketentuan hukum yang berlaku di Republik Indonesia. Sebagai Pranata Pemerintahan Adat di Muara Sakal/muaro sako dipimpin oleh seorang Datuk batin yang pada saat ini dipimpin oleh Batin ke-12 yang bernamaH.ZARMI.

Berdasarkan Tambo Kerajaan Pelalawan, Batin Muara Sakal mempunyai kewenangan untuk mengatur dan mengambil keputusan terhadap Suku Maniling Muara Sako Kecamatan Langgam Kabupaten Pelalawan, wilayah kebatinan Muara Sakal masuk kedalam wilayah hukum Kabupaten Pelalawan dan secara Pranata Hukum Adat kebatinan Muara Sakal memiliki tanah ulayat hingga saat ini masih tetap terpelihara dengan baik dibawa kepepimpinan batin yang diwariskan Kebatinannya secara turun menurun sampai sekarang.

Meningkatnya kebutuhan akan tanah untuk keperluan pembangunan,dan meningkatnya konflik pertanahan termasuk tanah ulayat menjadikan isu tentang eksistensi masyarakat adat dalam mempertahankan hak atas tanah ulayatnya perlu mendapat pemikiran yang proporsional.

\section{Kajian Pustaka}

Hukum adat Merupakan seperangkat norma atau aturan, baik yang tertulis maupun tidak tertulis, yang hidup dan berlaku untuk mengatur tingkah laku manusia yang bersumber pada nilai budaya bangsa 
Indonesia, yang diwariskan secara turun temurun, yang senantiasa ditaati dan dihormati untuk keadilan dan ketertiban masyarakat, dan mempunyai akibat hukum atau sanksi. ${ }^{7}$

Adapun subjek dari hukum adat adalah masyarakat hukum adat, dimana Masyarakat adat memiliki hak-hak yang harus dihormati, dilindungi, dandipenuhi oleh setiap negara dimana masyarakat tersebut berada. Dalam dokumen yang diterbitkan oleh NZ Human Rights dikemukakan 37 (tiga puluh tujuh) hak masyarakat adat, yaitu, 2 (dua) hak yang disebutkan yaitu: (1) Recognition and protection of their lands and resources; (2) Fair processes for dealing with their rights to lands and resources. ${ }^{8}$

Pengertian masyarakat adat secara konkrit dituangkan dalam Pasal 1 ayat (3) Peraturan Menteri Nomor 5 Tahun 1999 tentang Pedoman Penyelesaian Masalah Hak Ulayat Masyarakat Adat yang diterbitkan oleh Menteri Negara Agraria / Kepala Badan Pertanahan Nasional diatur bahwa masyarakat hukum adat adalah sekelompok orang yang terikat oleh tatanan hukum adatnya sebagai warga bersama suatu persekutuan hukum karena kesamaan tempat tinggal ataupun atas dasar keturunan. ${ }^{9}$

Hak tertinggi yang dimiliki masyarakat hukum adat adalah hak ulayat, ${ }^{10}$ Konsep hak ulayat yang dipakai dalam UUPA adalah apa yang dalam literatur hukum disebut dengan beschikkingsrecht. Beschikkingsrecht sendiri pertama kali diperkenalkan oleh Van Vollenhoven. Van vollenhoven menyebutkan bahwa Beschikkingrecht

7 Pasal 1 angka 15 Peraturan Daerah Provinsi Riau Nomor 2 Tahun 2019 Tentang Susunan Kelembagaan, Pengisian Jabatan Dan Masa Jabatan Kepala Desa Adat

${ }^{8}$ Ahmad Redi, Yuwono Prianto, Tundjung Herning Sitabuana dan Ade Adhari, Konstitusionalitas Hak Masyarakat Hukum Adat atas Hak Ulayat Rumpon di Provinsi Lampung, Jurnal Konstitusi, Volume 14, Nomor 3, September 2017, hlm. 471

${ }^{9}$ Rikardo Simarmata, 2006, Hukum Terhadap Masyarakat Adat di Indonesia, Jakarta : UNDP,hlm. 14

${ }_{10}$ Djamanat Samosir, Legalisasi Hak Ulayat Masyarakat Hukum Adat, Jurnal Masalah-Masalah Hukum Jilid 41, Nomor 3, Tahun 2012, hlm. 237 
tidak dapat dipisahkan dari hak yang melekat pada suatu masyarakat adat, yang pada dasarnya terarah kepada tanah dalam teritorialnya.

Hak ulayat merupakan hak yang melekat sebagai kompetensi khas pada masyarakat hukum adat, berupa wewenang/kekuasaan untuk mengurus dan mengatur tanah dan isinya, dengan daya laku ke dalam dan ke luar masyarakat hukum adat itu. Sifat yang khas tersebut, seperti tidak dapat dipindahtangankan atau bersifat kembang kempis, menjadikan hak ulayat sebagai hak yang istimewa. ${ }^{11}$

Hak Ulayat dalam Undang-Undang Pokok Agraria, menurut Budi Harsono memiliki dua aspek, yaitu pertama aspek publik, masudnya adalah dimana kewenangan dan subjek hak ulayat, yaitu masyarakat hukum adat untuk mengatur pengelolaan dan pemanfaatan ulayat mereka, yang meliputi kewenagan membuat perencanaan, peruntukan dan pemeliharaan dari taha ulayat bersangkutan selain itu juga kewenangan dalam mengatur dan mengendalilan perbuatan hukum yang berkaitan dengan ulayat serta kewenangan untuk menyerahkan atau memberi izin kepada orang, baik untuk masyarakat hukum adatnya sendiri atau orang luar untuk memanfaatkan bagian-bagain dari ulayat mereka, artinya kewenangan yang bersifat publik tidak mengadung unsur kepemilikan akan tetapi hanya hak memanfaatkan dan mengausai oleh masyarakat hukum adat. ${ }^{12}$

Selain aspek publik ada aspek keperdataan dalam hak ulayat, maksud aspek keperdataan dalam hak ulayat pada prinsipnya ulayat dimiliki oleh masyarakat hukum adat (Hak Komunal) dan hak ini tidak bisa diserahkan kepada siapa saja termasuk pemerintah, karena hak ini ada pada masing-masing individu anggota masyarakat hukum adat dan dalam melakukan perbuatan hukum mengani ulayat atas nama seluruh

${ }^{11}$ Adrianus Jerabu, 2014, Pengakuan Dan Perlindungan Hukum Terhadap Hak Ulayat Atas Tanah Masyarakat Hukum Adat Dalam Rangka Otonomi Daerah di Desa Colol Kecamatan Pocoranaka Timur Kabupaten Manggarai Timur (studi kasus). Jurnal Magister Ilmu Hukum , UAJY, hlm. 3

12 Budi Harsono, 2005, Hukum Agraria Indonesia: Sejarah Pembentukan Undang-Undang Pokok Agraria Isi dan Pelaksanaan, Jakarta, Djambatan, hlm. 76 
masyarakat hukum adat kewenangan untuk melakukan perbuatan hukum itu dilakukan oleh pimpinan yang diakui oleh masyarakat hukum adat, dalam hal ini Kabatinan Muara Sakal yang terletak di Kelurahan Langgam Kecamatan Langgam Kabupaten Pelalawan pemimpim yang diangkat dan diakui serta diberikewenangan untuk melakukan perbuatan hukum dalam aspek keerdataan adalah batin. Kewengan keperdataan yang dimiliki terdiri dari :

(1) Kewenangan memanfaatkan tanah ulayat

(2) Kewenangan mengadakan perjanjian dengan pihak lain terhadap pemanfaatan dari tanah ulayat.

(3) Kewenangan secara hukum bertindak untuk dan atas nama masyarakat adat baik diluar pengadilan maupun dalam pengadilan dalam mempertahankan hak atas tanah ulayatnya.

\section{Metode Penelitian}

Adapun Penelitian ini adalah penelitian hukum normatif. Menurut Zainuddin Ali, penelitian hukum normatif atau biasa disebut penelitian yuridis normatif ${ }^{13}$ oleh Soerjono Soekanto dan Sri Mamudji dijelaskan bahwa pada penelitian hukum normatif, bahan pustaka merupakandata dasar yang dalam ilmu penelitian digolongkan sebagai data sekunder. ${ }^{14}$ Penelitian ini menggunakan metode kualitatif dengan penyajian analisis secara deskriptif, yaitu usaha untuk mengumpulkan, menyusun, dan menginterpretasikan data yang ada dan menganalisa objek yang akan diteliti dengan merujuk pada prosedur-prosedur riset yang menghasilkan data kualitatif.

\footnotetext{
${ }^{13}$ Zainuddin Ali, Metode Penelitian Hukum, Sinar Grafika, Jakarta, 2014, hlm. 12.

14 Soerjono Soekanto dan Sri Mamudji, Penelitian Hukum Normatif. Suatu Tinjauan Singkat, RajaGrafindo Persada, Jakarta, 2006, hlm. 24.
} 


\section{Hasil dan Pembahasan}

\section{A. Eksistensi Masyarakat Adat Kebatinan Muara Sakal Kabupaten Pelalawan}

Kebatinan Muara Sakal merupakan Batin Kehormatan yang diberikan oleh Kesultanan Kerajaan Pelalawan pada masa Kerajaan tersebut. Menurut sejarah sehingga Batin Muara Sakal bisa menjadi Batin Kehormatan di Kerajaan Pelalawan berdasarkan Tombo Kerajaan Pelalawan dan Tombo Kebatinan Segati menerangkan bahwa pada dahulunya wilayah Kerajaan Pelalawan tepatnya di Muara Sakal/ Muara Sako, terjadi perperangan dengan Kerajaan Siak, kemudian selanjutnya Kesultan Pelalawan menyuruh atau memerintahkan ke Batinan Segati untuk melawan Kerajaan Siak, kemudian dalam perang itu Kebatinan Segati dibantu oleh Hulu Balang Suku Maniling dari Kerajaan Pagaruyung, sehingga berhasilah dalam perang tersebut, Kemudian atas jasa Hulu Balang Suku Maniling tersebut, kemudian Kesultanan Kerajaan Pelalawan memberikan Anugrah kepada Hulu Balang Suku Maniling dengan Batin Kerhormatan dan karena Hulu Balang Suku Maniling telah menjadi Batin Kehormatan oleh Sultan Kerajaan Pelalawan, maka diberikan tanah untuk wilayah Kebatinannya. Sultan Kerajaan Pelalawan memerintahkan kepada Kebatinan Segati untuk memberikan tanah, selanjutnya oleh Ke Batinan Segati diberikanlah tanah Ulayatnya yang berada di Muara Sako/Muara Sakal dan semenjak itulah berdirinya Kebatinan Muara Sako/Muara Sakal.

Satjipto Rahardjo ${ }^{15}$ mengungkakan empat klausula yuridis yang menjadi kriteria eksistensi masyarakat hukum adat adalah:

a. "Sepanjang masih hidup"

\footnotetext{
${ }^{15}$ Hendra Nurtjahjo dan Fokky Fuad, 2010, Legal Standing Kesatuan Masyarakat
} Hukum Adat Dalam Berperkara di Mahkamah Konstitusi, Jakarta : Salemba Humanika, hlm. 97 
Kita tidak semata-mata melakukan pengamatan dari luar, melainkan juga dari dalam, dengan menyelami perasaan masyarakat setempat (pendekatan partisipatif).

b. "Sesuai dengan perkembangan masyarakat"

Syarat ini mengandung resiko untuk memaksakan (imposing) kepentingan raksasa atas nama "perkembangan masyarakat". Tidak memberi peluang untuk membiarkan dinamika masyarakat setempat berproses sendiri secara bebas.

c. "Sesuai dengan prinsip NKRI"

Kelemahan paradigma ini melihat NKRI dan masyarakat adat sebagai dua antitas yang berbeda dan berhadap-hadapan.

d. "Diatur dalam undang-undang"

Indonesia adalah Negara berdasar hukum, apabila dalam Negara yang demikian itu segalanya diserahkan kepada hukum, maka kehidupan sehari-hari tidak akan berjalan dengan produktif.

Undang-Undang No. 41 tahun 1999 tentang Kehutanan, mengatur kriteria keberadaan masyarakat adat. Keberadaan masyarakat adat diakui sepanjang:

1. Masyarakatnya masih dalam bentuk paguyupan.

2. Ada kelembagaan dalam perangkat penguasa adatnya

3. Ada wilayah hukum adatnya yang jelas

4. Ada pranata hukum, khususnya peradilan adat yang masih ditaati, dan masih mengadakan pemungutan hasil hutan di wilayah hutan dan sekitarnya untuk pemenuhan kebutuhan hidup sehari-hari.

Kemudian, berdasarkan UU No. 18 Tahun 2004 tentang Perkebunan, keberadaan masyarakat adat diakui sepanjang:

1. Masyarakatnya masih dalam bentuk paguyupan.

2. Ada kelembagaan dalam perangkat penguasa adatnya.

3. Ada wilayah hukum adatnya yang jelas.

4. Ada pranata hukum, khususnya peradilan adat yang masih ditaati, dan 
5. Ada pengukuhan dengan peraturan daerah.

Demikian juga berdasarkan Pasal 3 Peraturan Menteri Agraria dan Tata Ruang/Kepala BPN No. 9 Tahun 2015 tentang Tatacara Penetapan Hak Komunal Atas Tanah Masyarakat Hukum Adat Dan Masyarakat Yang Berada Dalam Kawasan Tertentu, bahwa persyaratan keberadaan masyarakat hukum adat adalah:

1. Masyarakat masih dalam bentuk paguyupan.

2. Ada kelembagaan dalam perangkat penguasa adatnya.

3. Ada wilayah hukum adatnya yang jelas.

4. Ada pranata dan perangkat hukum yang masih ditaati.

Bahwa dalam Sejarah, keberadaan Masyarakat Hukum Adat di negeri ini sudah ada jauh sebelum Indonesia merdeka. Pada masa itu kejayaan masyarakat hukum adat dapat ditelusuri melalui penguasaan wilayah yang mereka diami, keberadaan hukum adat yang mengatur dan mempengaruhi kehidupan sosial masyarakat hukum adat, keberadaan lembaga adat yang tidak hanya sekedar sebagai lembaga yang diisi oleh para pemuka adat tetapi juga sebagai pengawal pemberlakuan hukum adat yang ada yang kesemuanya hingga kini masih terlihat di beberapa wilayah di Indonesia dan salah satunya di kampung Muara Sakal Kecamatan Langgam Kabupaten Pelalawan .

Dapat disimpulkan klausula yuridis yang menjadi kriteria eksistensi masyarakat hukum adat di Indonesia antara lain: Pertama, Masyarakat masih dalam bentuk paguyupan.

Bahwa keberadaan kebatinan Muara Sakal, berawal pada masa Kerajaan Pelalawan yang tumbuh dan berkembang seiring sejalan dengan Kerajaan Pelalawan dimana Pranata Pemerintahan Adat, harta kekayaan dan/atau benda-benda adat, norma hukum adatnya serta kesatuan masyarakat hukum adatnya yang bersifat teritorial/unsur wilayah hukum adatnya masih terpelihara dengan baik hingga saat ini dan tidak bertentangan dengan ketentuan hukum yang berlaku di Republik Indonesia. Sebagai Pranata Pemerintahan Adat di Muara Sako dipimpin 
oleh Kebatinan yang pada saat ini dipimpin oleh Batin ke-12 yang bernama H.ZARMI yang bergelar Batin Muara Sakal/Batin Muara Sako

Kebatinan Muara Sakal Masyarakatnya masih dalam bentuk paguyupan, berdasarkan Tambo Kerajaan Pelalawan, Batin Muara Sakal mempunyai kewenangan untuk mengatur dan mengambil keputusan terhadap Suku Maniling Muara Sako Kecamatan Langgam Kabupaten Pelalawan.

Kedua, Ada kelembagaan dalam perangkat penguasa adatnya.

Adapun di Muara Sako selain ada Pemerintahan berdasarkan Pemerintah Kabupaten Pelalawan, juga ada Pemerintahan secara Hukum Adat yang dipimpin oleh seorang Batin yang disebut Kebatinan Muara Sakal, hingga saat ini berdasarkan Tombo Muara Sako, yang diriwayatkan kepada anak kemanakan Batin Muara Sakal dari awalnya sampai sekarang berjumlah 12 orang Batin yaitu:

1. Batin ke 1 (satu) bernama Raja Mahbunsu bergelar Batin Muara Sakal

2. Batin ke 2 (dua) bernama Tuk Suka bergelar Batin Muara Sakal

3. Batin ke 3 (tiga) bernama Batin Hitam bergelar Batin Muara Sakal

4. Batin ke 4 (empat) bernama ATIP bergelar Batin Muara Sakal

5. Batin ke 5 (lima) bernama Tuk Engku Nan Panjang bergelar Batin Muara Sakal

6. Batin ke 6 (enam) bernama GANTANG bergelar Batin Muara Sakal

7. Batin ke 7 (Tujuh) bernama ATIP bergelar Batin Muara Sakal

8. Batin ke 8 (delapan) bernama Tuk Sanjaya ATIP bergelar Batin Muara Sakal

9. Batin ke 9 (sembilan) bernama Mak Suluh bergelar Batin Muara Sakal

10. Batin ke 10 (sepuluh) bernama TINDIH ATIP bergelar Batin Muara Sakal 
11. Batin ke 11 (sebelas) bernama H.M. YUNUS bergelar Batin Muara Sakal

12. Batin ke 12 (dua belas) bernama H. ZARMI memimpin dari tanggal 25 Agustus 2018 sampai dengan sekarang bergelar Batin Muara Sakal

Adapun tugas Batin Muara Sakal yakni mempunyai kewenangan untuk mengatur dan mengambil keputusan terhadap persoalan-persoalan yang ada disuku Maniling Kecamatan Langgam Kabupaten Pelalawan, didalam menjalankan tugasnya Batin Muara Sakal dibantu oleh:

1. Antan-antan

2. Rangkayo Mudo

3. Panglimo Putih

4. Tuo Anak Jantan

5. Tuo Anak Padusi

6. Sumondo Tuo

Ketiga, Ada wilayah hukum adatnya yang jelas.

Dalam hukum adat, hak penguasaan atas tanah yang tertinggi adalah hak ulayat yang merupakan serangkaian wewenang dan kewajiban suatu masyarakat hukum adat, yang berhubungan dengan tanah yang terletak dalam lingkungan wilayahnya yang merupakan pendukung utama penghidupan dan kehidupan masyarakat yang bersangkutan sepanjang masa. $^{16}$

Kebatinan Muara Sakal mempunyai Tanah Ulayat dan tanah ulayat tersebut terletak diwilayah antara lain:

1. Kampung Muara Sako

2. Kalapas Hitam

3. Kalapas Putih

4. Danau Teluk Jauh

5. Tamiang

${ }^{16}$ Tampil Anshari Siregar, Undang-Undang Pokok Agraria Dalam Bagan, Kelompok Studi Hukum dan Masyarakat Fakultas Hukum USU, Medan, 2006, hlm. 61. 
6. Sungai Sualam

7. Kompe Anggeh

8. Pematang Siabung

9. Danau Sarang Unggeh

10. Titian Umbai

Wilayat Hukum adat Kebatinan Muara Sako Kecamatan Langgam yang diperdapatnya dari Kebatinan Segati, sebagai hak ulayat secara turun menurun sampai sekarang dengan penjelasan sebagai berikut:

1. Dari Bakal Paku Tirai melalui Tepian Umbai menuju Pematang Piabung turun ke Teluk Lindung Bulan menyeberang Sungai, Kampar Kiri melalui Kempas Anggas menyeberang Sungai Kampar Kanan menuju Kuala Sungai Kalapas.

2. Dari Kuala Sungai Kalapas mudik sampai Keguguk Sungai Kalapas Kanan meniti Pematang sampai kehulu Sunggai Musi anak Sungai Kampar menuju Teluk Jao dipinggir Sungai Kampar.

3. Dari Teluk Jao melalui Genting Danau Sarang Unggas menuju Ujung Rasau Panjang dipinggir Sungai Segati, selanjutnya mengikuti Sungai Segati sampai kembali ke Bakal Paku Tirai.

Sesuai dengan perkembangan Provinsi Riau berdasarkan UndangUndang Republik Indonesia Nomor : 53 tahun 1999, Kabupaten Kampar telah dilakukan pemekaran menjadi beberapa wilayah Kabupaten diantaranya adalah termasuk Kabupaten Pelalawan, setelah pemekaran dimaksud, wilayah kebatinan Muara Sakal masuk kedalam wilayah hukum Kabupaten Pelalawan dan secara Pranata Hukum Adat Kebatinan Muara Sakal hingga saat ini masih tetap terpelihara dengan baik dalam masyarakat adatnya dan tanah ulayat masih tetap terjaga dengan baik dibawah kepemimpinan para Batin yang telah ditunjuk untuk itu.

Tanah ulayat Kebatinan Muara Sakal dirawat secara terus menerus oleh anak kemanakan Kebatinan Muara Sakal, diantaranya yakni anak kemanakan diberikan hak untuk menikmati hasil tanah atau tanaman yang berada diatasnya untuk memenuhi kebutuhan sehari hari, diantaranya dengan cara suak sungai untuk mencari ikan dan rotan-rotan dikawasan 
tanah ulayat, akan tetapi tanah ulayat tersebut tidak boleh dimiliki secara pribadi tanpa izin dari Batin Kebatinan Muara Sakal.

Keempat, Ada pranata dan perangkat hukum yang masih ditaati.

Hukum adat itu adalah suatu kompleks norma-norma yang bersumber pada perasaan keadilan rakyat yang selalu berkembang serta meliputi peraturan-peraturan tingkah laku manusia dalam kehidupan sehari-hari dalam masyarakat, sebagian besar tidak tertulis, senantiasa ditaati dan dihormati oleh rakyat, karena mempunyai akibat hukum (sanksi). Hukum Adat berurat-akar pada kebudayaan tradisional, hukum adat adalah suatu hukum yanag hidup karena ia menjelmakan perasaan hukum rakyat yang nyata. ${ }^{17}$

Pranata Hukum Adat Kebatinan Muara Sakal hingga saat ini masih tetap terpelihara dengan baik dalam masyarakat adatnya dan tanah ulayat masih tetap terjaga dengan baik dibawah kepemimpinan Batin. Untuk pergantian batin yang memimpin Kebatinan Muara Sakal menggugakan pranata adat/atauran yang berlaku di kebatinan Muara Sakal dimana gelar batin muara sakal di turunkan kepada keponakan laki-laki dari anak sadara perempuan dan adapun yang melakukan Prosesi Penobatan /Penabalan Adat dilakukan oleh anak Tuo Anak Padusi (anak Perempuan yang paling tua) di kebatinan Muara Sakal.

Seluruh tokoh adat dan anak kemenakan Batin Muara Sako mentaati aturan terkait dengan tanah ulayat tidak boleh dimiliki secara pribadi dan Tapal Batas tanah ulayat batin Muara Sakal tidak dapat di pindahkan dan di ganggu gugat karena tapal batas tersebut sudah dibuat sejak berdirinya Kerajaan Batin Ajo Segati berkisar Abad ke-13 M, siapa yang memindahkan dan merubah batas tersebut akan mendapat kualat (dimakan sumpah)

\footnotetext{
${ }^{17}$ Ana Suheri, Hukum adat sebagai pranata hukum Penangkal arus globalisasi, morality : Jurnal IImu Hukum, Desember 2017, Volume 3 Nomor 2 HIm. 26
} 
Berdasarkan penjelasan diatas dapat ketahui bahwa eksistensi atau keberadaan dari Batin Muara Sakal berserta dengan tanah adat/ulayatnya nyata-nyata masih diakui keberadaannya dalam masyarakat Kerajaan Pelalawan, dan ini selaras dengan ketentuan Pasal 3 Undang-Undang No. 5 Tahun 1960 tentang Undang-Undang Pokok Agraria maka keberadaan hak ulayat dan hak-hak masyarakat hukum adat sepanjang kenyataan masih ada dan tidak bertentangan dengan undangundang dan peraturan-peraturan yang lebih tinggi

\section{B. Eksistensi Masyarakat Adat Kebatinan Muara Sakal Dalam Mempertahankan Hak Atas Tanah Ulayat}

Hak ulayat dapat dikatakan semacam hak kekuasaan, hak menguasai bahkan menyerupai semacam kedaulatan suatu persekutuan hukum adat (adat gemeenschap) atas suatu wilayah. ${ }^{18}$

Wilayah kekuasaan (beschikkingebied) persekutuan itu adalah milik persekutuan yang pada asasnya bersifat tetap, artinya perpindahan hak milik atas wilayah ini adalah tidak diperbolehkan. Dalam kenyataannya terdapat pengecualian-pengecualian, oleh karenanya di atas tadi ditegaskan pada dasarnya bersifat tetap.

Di Indonesia, eksistensi masyarakat hukum adat mendapat tantangan yang cukup besar dari berbagai hal dan pihak, mulai dari persoalan sosial yang dihadapi berkaitan dengan masuknya budayabudaya asing yang dapat menggerus budaya lokal yang selama ini hidup dan menghidupi masyarakat hukum adat, hingga pada persoalan yang kerap menimbulkan konflik yang berkepanjangan seperti "perampasan" wilayah adat (teritorial) baik oleh pihak swasta (korporasi) maupun oleh negara sendiri.

Selama ini, hal yang masih menjadi sumber konflik utama yang terjadi pada masyarakat hukum adat adalah mengenai wilayah adatnya,

\footnotetext{
${ }^{18}$ Jhon Salindeho, Masalah Tanah Dalam Pembangunan, Sinar Grafika, Jakarta, 1993,
} hlm. 282. 
kendala yang dihadapi oleh masyarakat hukum adat yaitu ketidakjelasan mengenai luas dan batas wilayah adat yang mereka kuasai sehingga ketika ada pihak lain di luar persekutuan mereka yang mengklaim wilayah adat mereka, posisi masyarakat hukum adat cenderung lemah di hadapan hukum. ${ }^{19}$ Persoalan tersebut juga terjadi terhadap masyarakat hukum adat dan tanah ulayat Kebatinan Muara Sakal.

Hak ulayat meliputi semua tanah yang ada dalam lingkungan wilayah masyarakat hukum yang bersangkutan, baik yang sudah dimiliki oleh seseorang maupun yang belum. Dalam lingkungan hak ulayat tidak ada tanah sebagai res nullius. Umumnya, batas wilayah hak ulayat masyarakat hukum adat teritorial tidak dapat ditentukan secara pasti. ${ }^{20}$

Konflik tentang "pencaplokan" wilayah adat oleh perusahaan/korporasi baik yang bergerak di bidang perkebunan, pertambangan maupun bidang-bidang lainnya belakangan ini kian marak terjadi. Hampir pada seluruh daerah di tanah air yang terdapat masyarakat hukum adat mengalami hal yang demikian. Dalam kondisi tersebut tidak jarang posisi masyarakat hukum adat berada pada posisi yang lemah baik secara hukum maupun secara politik.

Kondisi yang sama juga dialami oleh masyarakat hukum adat kebatinan Muara Sakal, dimana beberapa wilayah hukum adatnya di kuasa oleh perusahaan perkebunan dan dikuasai juga masyarakat secara perorangan.

Persekutuan masyarakat hukum adat dalam memelihara dan mempertahankan hak ulayat dilakukan dengan cara $^{21}$ :

a. Persekutuan berusaha meletakkan batas-batas di sekeliling wilayah kekuasaannya itu. Tetapi usaha ini lazimnya tidak dapat

${ }^{19}$ Aryo Subroto, Peran Negara Dalam Menjaga Eksistensi Masyarakat Hukum, Jurnal Yuriska: Jurnal Ilmiah Hukum, Vol. 11 No. 1, hlm. 72

${ }_{20}$ Al Jamil Febriani, Penyelesaian Sengketa Tanah Ulayat Antara Masyarakat Adat Senama Nenek Dengan Ptpn V Di Kenegerian Senama Nenek Kecamatan Tapung Hulu Kabupaten Kampar Provinsi Riau, Premise Law Jurnal Vol 22 (2017): Volume 22 , hlm. 12

${ }^{21}$ Bushar Muhammad,1881, Pokok-Pokok Hukum Adat, Jakarta: PT Pradnya Paramita, hlm. 104 
diselenggarakan secara sempurna, lebihlebih apabila masyarakat persekutuan tersebut, tempat tinggalnya tersebar dalam pendukuhan-pendukuhan kecil atau apabila daerah persekutuan tersebut, meliputi tanah-tanah kosong yang luas.

b. Menunjuk pejabat-pejabat tertentu yang khusus bertugas mengawasi wilayah kekuasaan persekutuan yang bersangkutan. Petugas-petugas itu sering disebut jarring (Minangkabau), teterusan (Minahasa), kepala kewang (Ambon), lelipis lembukit (Bali). Disamping petugas khusus ini, biasanya diadakan pula patrol perbatasan.

c. Dilakukannya surat-surat pikukuh atupun piagam yang dikeluarkan oleh raja-raja dahulu, yang dikeluarkan sebagai keputusan hakimhakim kerajaan ataupun hakim-hakim pemerintah kolonial Belanda dahulu atau oleh pejabat-pejabat pamong praja lainnya yang berwenang.

Masyarakat hukum adat Muara Sakal dalam mempertahankan hak atas tanah ulayat dari "perampasan" wilayah adat (teritorial) atau dari penguasaan oleh pihak swasta (korporasi) maupun masyarakat secara perorangan yang menguasai tanah ulayat Masyarakat hukum adat Muara Sakal tanpa hak. Masyarakat hukum adat Muara Sakal telah melakukan berbagai upaya mulai dari melakukan tindakan persuasif dengan pihak yang bersangkutan sampai menempuh jalur hukum melalui pengadilan.

Tercatat pada tanggal 15 Desember 2017 Batin ke 11 (sebelas) bernama H.M. YUNUS bergelar Batin Muara Sakal mengajukan gugatan di Pengadilan Negeri Pelalawan dengan Register Nomor : 128/SK.P/2017/PN.PLW dimana PT. Rimbun Sawit Sejahtera sebagai Tergugat I dan PT. Nusa Prima Manunggal sebagai Tergugat I. Dalam putusannya majelis hakim memutuskan antara lain : "Menyatakan Penggugat Selaku Batin Muara Sakal (Muaro Sako) yaitu Pemangku Adat yang menurut Adat memimpin Pesukuan dan menjadi Pucuk Adat Istiadat dilingkungan Pesukuannya di Kerajaan Pelalawan adalah selaku pemilik 
yang sah atas tanah/wilayah adat seluas lebih kurang 5.605 Ha (lima ribu enam ratus lima hektar) yang terletak pada dua tempat yaitu seluas lebih kurang $1.816 \mathrm{Ha}$ (seribu delapan ratus enam belas hektar) terletak dikenal setempat dengan Areal Kalapas I dan seluas lebih kurang $3.789 \mathrm{Ha}$ (tiga ribu tujuh ratus delapan puluh sembilan hektar) terletak dikenal setempat dengan Areal Kalapas II; dan Menyatakan Tergugat I PT. Rimbun Sawit Sejahtera dan Tergugat II PT. Nusa Prima Manunggal telah melakukan perbuatan melawan hukum (onrecht matigedaad)" 22 akan tetapi pada tingkat banding dan kasasi H.M. YUNUS yang mewakili masyarakat adat kebatinan Muara Sakal dikalahkan.

Selain itu pada tanggal 27 Agustus 2020, Batin ke 12 (dua belas) bernama $\mathrm{H}$. ZARMI yang mewakili masyarakat adat Kebatinan Muara sakal juga pernah mengajukan gugatan di Pengadilan Negeri Pelalawan dengan Register Nomor : 25/Pdt.G/2020/PN Plw Dimana yang menjadi objek sengketa adalah Tanah Ulayat Masyarakat Muara Sakal yang berada di Danau Teluk Jao seluas $\pm 3,8$ hektar, selang beberapa hari setelah itu Batin ke 12 bernama H. ZARMI kembali mengajukan gugatan di Pengadilan Negeri Pelalawan dengan Register Nomor : 26/Pdt.G/2020/PN Plw yang terdaftar pada tanggal 7 september 2020 dan yang menjadi objek sengketa adalah Tanah Ulayat Masyarakat Muara Sakal yang berada di Tamiang. Kedua gugatan tersebut diatas dapat dimenangkan oleh $\mathrm{H}$. ZARMI yang mewakili masyarakat adat Kebatinan Muara Sakal.

Dari penjelasan diatas dapat dilihat bahwa masyarakat adat Kebatinan Muara Sakal dalam mempertahankan tanah ulayat yang menjadi hak masyarakat adatnya masih tetap eksis keberadaannya. 


\section{Kesimpulan dan Saran}

Keberadaan hak ulayat atas tanah masyarakat hukum adat Kebatinan Muara Sakal, pada kenyataannya masih dikelola dan dikuasai bersama oleh masyarakat hukum adat yang diwakili oleh sistem kepemimpinan dalam suatu kelembagaan adat beserta kewenangankewenangan yang melekat padanya dimana Kebatinan Muara Sakal di pimpin oleh seorang Batin. Masyarakat tersebut masih terikat oleh tatanan hukum adat mengenai pengurusan, penguasaan penggunaan hak ulayat atas tanah yang berlaku, diakui dan ditaati oleh masyarakat hukum adat setempat dan masih mempertahankan hak atas tanah ulayat mereka dari para pihak yang menguasainya tanpa hak ini dibuktikan dengan ada gugatan kepengadilan oleh Kebatinan Muara Sakal dalam hal ini diwakili oleh seorang batin sebagai pimpinan adat di Kebatinan Muara Sakal.

\section{Daftar Pustaka}

Adrianus Jerabu, Pengakuan Dan Perlindungan Hukum Terhadap Hak Ulayat Atas Tanah Masyarakat Hukum Adat Dalam Rangka Otonomi Daerah di Desa Colol Kecamatan Pocoranaka Timur Kabupaten Manggarai Timur (studi kasus). Jurnal Magister IImu Hukum , UAJY, 2014

Ahmad Redi, Yuwono Prianto, Tundjung Herning Sitabuana dan Ade Adhari, Konstitusionalitas Hak Masyarakat Hukum Adat atas Hak Ulayat Rumpon di Provinsi Lampung, Jurnal Konstitusi, Volume 14, Nomor 3, September 2017.

Al Jamil Febriani, Penyelesaian Sengketa Tanah Ulayat Antara Masyarakat Adat Senama Nenek Dengan Ptpn V Di Kenegerian Senama Nenek Kecamatan Tapung Hulu Kabupaten Kampar Provinsi Riau, Premise Law Jurnal Vol, 22 , 2017.

Ana Suheri, Hukum adat sebagai pranata hukum Penangkal arus globalisasi, morality : Jurnal Ilmu Hukum, Volume 3 Nomor 2, Desember 2017.

Aryo Subroto, Peran Negara Dalam Menjaga Eksistensi Masyarakat Hukum, Jurnal Yuriska: Jurnal Ilmiah Hukum, Vol. 11 No. 1. 
Budi Harsono, Hukum Agraria Indonesia: Sejarah Pembentukan UndangUndang Pokok Agraria Isi dan Pelaksanaan, Jakarta, Djambatan, 2005.

Bushar Muhammad, Pokok-Pokok Hukum Adat, Jakarta: PT Pradnya Paramita, 1991.

Jhon Salindeho, Masalah Tanah Dalam Pembangunan, Sinar Grafika, Jakarta, 1993.

Djamanat Samosir, Legalisasi Hak Ulayat Masyarakat Hukum Adat, Jurnal Masalah-Masalah Hukum Jilid 41, Nomor 3, Tahun 2012.

Hendra Nurtjahjo dan Fokky Fuad, Legal Standing Kesatuan Masyarakat Hukum Adat Dalam Berperkara di Mahkamah Konstitusi, Jakarta : Salemba Humanika, 2010.

Nur Apri Ramadan I. Usman, Eksistensi Masyarakat Hukum Adat Dalam Penguatan Desa Adat Di Desa Bentenan Kabupaten Minahasa Tenggara, Jurnal, Lex Et Societatis, Vol. III/No. 7/ags/2015

Rikardo Simarmata, Hukum Terhadap Masyarakat Adat di Indonesia, Jakarta : UNDP, 2006.

Soerjono Soekanto dan Sri Mamudji, Penelitian Hukum Normatif. Suatu Tinjauan Singkat, RajaGrafindo Persada, Jakarta, 2006.

Tampil Anshari Siregar, Undang-Undang Pokok Agraria Dalam Bagan, Kelompok Studi Hukum dan Masyarakat Fakultas Hukum USU, Medan, 2006.

Zainuddin Ali, Metode Penelitian Hukum, Sinar Grafika, Jakarta, 2014.

Undang-Undang Dasar Negara Republik Indonesia Tahun 1945

Undang-Undang Nomor 6 Tahun 2014 tentang Desa

Peraturan Daerah Provinsi Riau Nomor 2 Tahun 2019 Tentang Susunan Kelembagaan, Pengisian Jabatan Dan Masa Jabatan Kepala Desa Adat.

Putusan Pengadilan Pelalawan Register Perkara nomor: 128/SK.P/2017/PN.PLW. 